\section{土木学会論文報告集}

第 339 号・1983 年 11 月

【論
文】

\title{
船舶衝突確率の推定モデル \\ PROBABILISTIC MODELLING OF SHIP COLLISION
}

\author{
黒 田 勝 彦*・喜 多 秀 行** \\ By Katsuhiko KURODA and Hideyuki KITA
}

\section{1. 緒雼}

水路の計画や設計を行う際，安全性に対する考虑は経 済性に 対するものと同様に不可欠なものである．昭和 40 年代以後, 船舶が大型化・高速化するとともに船舶 交通量が増加し，航路における輻軼が顕著となってきて いる. また，タンカーや LNG 船といった危険物輸送 船が増加し，一たび事故が発生すると経済的損失はもと より環境面においても甚大な被害をこうむることが予想 される.このような背景から, 海難事故の分析と事故防 止のための研究が要請されてきている.

海難事故のうち船体に損傷を受けるものは, 衝突, 乗 り揚げ, 転覆, 火災, 機関故障, 浸水に大別される.こ れらのうち，水路計画に資することを目的とする立場か ら交通事故的海難（衝突, 乗り揚げ）に着目し, また, 福島 ${ }^{11}$ にると全海難に占める衝突の割合は約 $60 \%$ と きわめて多いため, 著者らはまず衝突確率と水路・交通 特性との関係を明らかにしょらとした。

一般に, 海難は自然条件, 交通条件, 航路条件, 船舶
条件と運航者条件が相互に関連して生ずると考えられ る ${ }^{2}$. これらを著者らはそれぞれ, 自然条件, 交通, 水 路, 船舶, および操船者特性とよび，そこに含まれる諸 要因を表一1 のように分類した. 航路によっては, 防 波堤の設置などにより波浪や潮流といった一部の自然条 件も操作可能となる場合があるが，一般には，水路特性 と交通特性の一部が航路計画上の操作変数となり得る. すなわち, 交通特性の一部は航行規制の形で変更が可能 であり, 水路特性は障害物の除去, 航路の浚渫・拡幅, 航路標識の整備等の事故率減少策が, 限度はあるにせよ 人為的に行い得る. このために, 航路計画上の操作変数 と衝突確率との関係が, 定量的にかつ相互作用を考虑し 得る形で明らかにされる必要がある.

船舶衝突確率の推定に関する従来の研究は, ある要因 と事故率との単相関を統計的に整理したものがほとんど であり, 航路の計画, 設計に直接適用し得る形でシステ マティックな分析を行った研究は, シミュレーションに よる杉崎ほか ${ }^{3)}$, 木俣・石崎 ${ }^{4}$, 待ち行列理論の適用を はかった原(5),6), 航路外一出る際の衝突確率を扱った $\mathrm{Curtis}^{7)}$, 出会(確率までを求めた藤井 ${ }^{8)}$, Lewisson ${ }^{9)}$,

\section{表一1衡突確率に影響を及ぼす要因}

\begin{tabular}{|c|c|c|c|c|}
\hline \multicolumn{2}{|c|}{ Operational } & \multicolumn{3}{|c|}{ Non-Operational } \\
\hline $\begin{array}{c}\text { Channel } \\
\text { Characteristics }\end{array}$ & Traffic characteristics & $\begin{array}{c}\text { Navigators } \\
\text { Characteristics }\end{array}$ & Ship Characteristics & Natural Conditions \\
\hline $\begin{array}{l}\text { 1. Fairway Width } \\
\text { 2. Fairway Length } \\
\text { 3. Depth } \\
\text { 4. Curvature } \\
\text { 5. Fairway Crossing } \\
\text { 6. Navigation Mark } \\
\text { 7. Obstacles } \\
\text { 8. Channel Side Shape } \\
\text { etc. }\end{array}$ & $\begin{array}{l}\text { 1. Ship Size Distribution } \\
\text { 2. Sailing Velocity } \\
\text { Distribution } \\
\text { 3. Total Traffic Volume } \\
\text { 4. Traffic Volume Ratio in } \\
\text { Different Directions } \\
\text { 5. Crossing Traffic Volume } \\
\text { 6. Wake Position } \\
\text { Distribution } \\
\text { 7. Headway Distribution } \\
\text { etc. }\end{array}$ & $\begin{array}{l}\text { 1. Quality } \\
\text { 2. Illegal Sailing } \\
\text { 3. Bad Watching } \\
\text { 4. With or Without Pilot } \\
\text { etc. }\end{array}$ & $\begin{array}{l}\text { 1. Ship Size } \\
\text { 2. Speed Performance } \\
\text { 3. Steering Performance } \\
\text { 4. Stopping Performance } \\
\text { 5. Radar Equipment } \\
\text { etc. }\end{array}$ & $\begin{array}{l}\text { 1. Tidal Stream } \\
\text { 2. Wave } \\
\text { 3. Sight Distance } \\
\text { 4. Wind Direction } \\
\text { 5. Wind Force } \\
\text { 6. Weather } \\
\text { 7. Time etc. }\end{array}$ \\
\hline
\end{tabular}

* 正会員 工博 京都大学助教授 工学部交通土木工学教室

** 正会員 工修 京都大学助手 工学部交通土木工学教室 
以外には見当たらない.シミュレーションによる分析は 演算時間と演算費用の制約を受け，原のモデルは交通諸 特性が有するばらつきが到着時間間隔を除いて明示的に 考慮されていない，一方，Curtis は同航船の前方を回 り込んで航路を横切るといら特殊な状態のみを扱うもの であり，一般的な交通条件に対しては適用できない。 た Lewisson, 藤井については避航動態が考慮されてお らず，出会い確率と衝笑確率の間の理論的な関連づけに も欠ける.

前報 ${ }^{10)}$ で, 著者らは 表一1 に示した 航路計画上操作 可能な諸要因を組み込むとともに，船舶の避航動態を考 慮した船舶衝突確率推定モデルの基本プロセスを構築し た. 本報告は，これをもとに種々の改良を加え，航路設 計代替案の探索・評価の道具とし得る船舶衝突確率推定 モデルを提案するものである．そして，実績值と計算值 を比較してモデルの妥当性に検討を加え，モデルが有す る若干の問題点に対する議論を行う.

\section{2. 本モデルの概要}

\section{（1） モデルにおける推定プロセス}

図一1 は本モデルによる 1 隻 1 トリップ当たり衝突確 率および水路全体がもつ平均的衝突危険度を推定するプ ロセスを示したものである. 表一1 に示した船舶衝突に 関連する諸特性のうち，モデルに入力されるものは水路

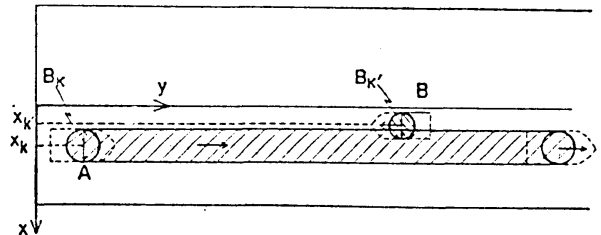

図一2 水路内での 2 船の出会い

特性と交通特性ならびに船舶特性であり，自然条件およ び操船者特性は, 平均的な状態あるいはばらつきの程度 が，観測值として取り込まれている交通特性に反映され ているものと考えている.

まず，交通特性，水路特性と船舶特性から 2 船間の避 航失敗確率 (11) および水路内での出会い確率 (2) を算 出し, 両者から 2 船間の船型別基本衝突確率（3）を求 める. 一方, 交通特性から着目船が水路を通過する際に 出会う可能性のある船舶の隻数 (4) を求めておく.こ こまではすべて出会いの形態別（行き合い, 追い越し, 被追い越し）および両船の船型別に計算される.そして， (3) と (4) からある船型の船舶 1 隻が水路内で衝突する確 率（5)）を求め,これを船型に関する期待值演算を行うこ とにより，水路における船舶衝突危険度（6) を得る。

\section{（2）モデルの前提と避航動態のモデル化}

解析対象とする水路は延長 $L_{C}$, 幅 $W$ の一様な両側 通航水路である.この水路上を, 避航時を除いて船舶は 水路と平行に独立して直進し, 横切り船舶の存在はない

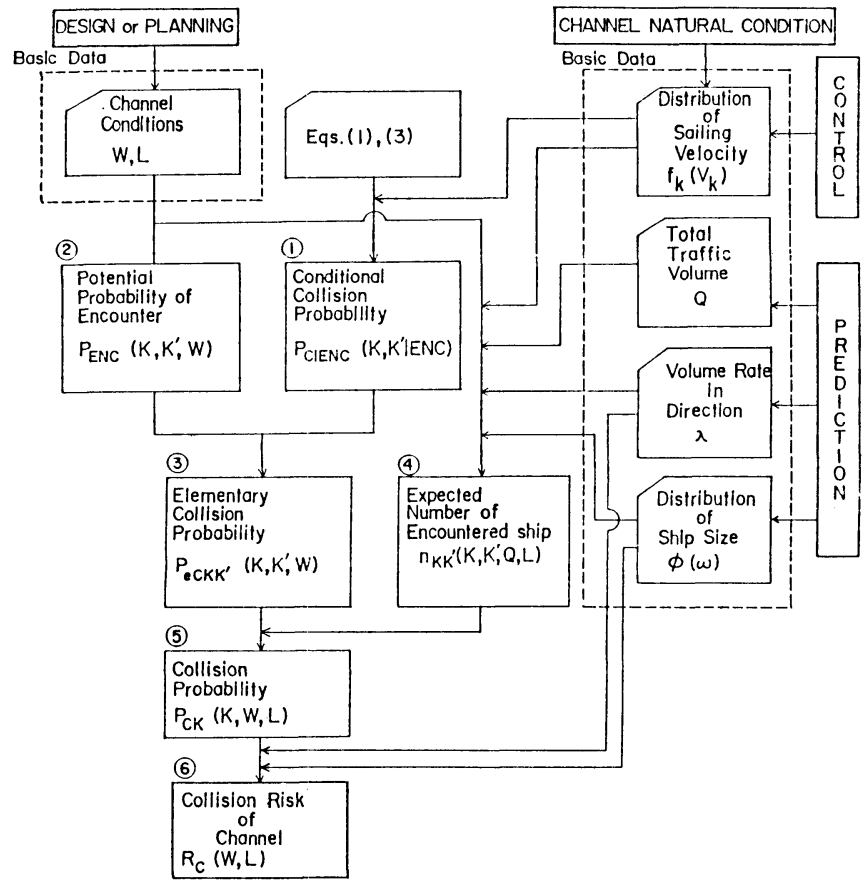

図一1＼cjkstart本モデルにおける推定プロセス
ものとする．図一2 に示すように，船舶は船幅 $B$ 直径とする円で表現され，この円が一部で も重なった場合を「衝突」，避航動作をとるこ となくそのまま進めば衝突に至る位置関係にあ る場合を「出会い」と定義する。なお，避航の 対象となる相手船は着目船の進路の延長線上を 航行し，この線上で出会うとの仮定を設けてい る。

避航の形態は行き合い, 追い越し, 被追い越 しの 3 種を考え, それぞれ反航船, 着目船より 速度の遅い同航船，着目船より速度の速い同航 船との避航に対応する．行き合いの場合（図一 3 (a)）は両船同時に避航を開始し, 追い越しの 場合（図一4(a)）は追い越しをかける船のみが 避航動作をとる．避航に伴う航跡は折線で表現 し，そのときの変針角を $\theta$ とする．避航中に両 船が接するような位置関係は，これ以上避航開 始が遅れれば避航動作をとったとしても衝突に 至るため,このような状態における避航開始時 点の両船の 距離を限界避航開始距離 (Critical Give-Way Starting Distance : C.G.W.S.-距 
(a) Glve-woy Motion in Head-on Situation

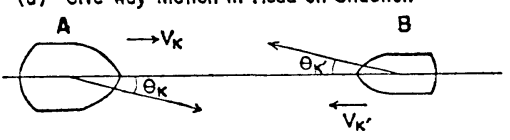

(b) Critical G.W.S.-Distance

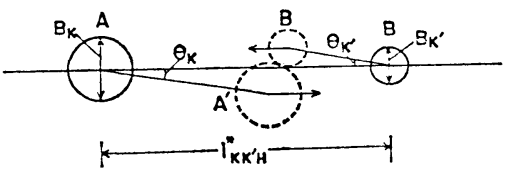

図一3行き合い時の避航動態

(a) Give-way Motion in Overtaking Situation

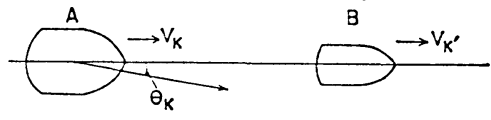

(b) Critical G.W.S.-Distance

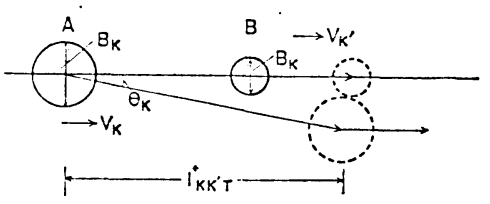

図一4 追い越し時の避航動態

離） $l^{*}$ とよぶ（図一3 (b)，4 (b)).

\section{（3）基本衝突確率}

船舶の避航開始距離 (Give-Way Starting Distance : G.W.S.-距離） l は個々の避航によって大きく異なる. 著者らは，ばらつきを有する避航開始距離が，本研究で 明示的に取り扱われる船舶特性や交通特性に依存する確 定值項と, 操船者の経験や天候などの本モデルで明示的 に取り扱っていないランダム項からなっているものと仮 定する. 観測結果 ${ }^{11)}$ より，避航開始距離は，行き合い (Head-on), 追い越し (Overtaking), 被追い越し(Overtaken) (以後，それぞれ添字 $H, T, O$ で表わす) に対 して以下の形で表わされる.ここで，確定值項は文献 11）で解析された結果を用い，ランダム項はこの確定值 項による推計值と実現值との残差を種々の説明変数に対 して解析した結果を用いている.

$$
\left.\begin{array}{l}
l_{k k^{\prime} H}=\alpha_{H}+\beta_{H} V_{k}+\gamma_{H} V_{k^{\prime}}+\delta_{H} \varepsilon_{H} \\
l_{k k^{\prime} T}=\alpha_{T}+\beta_{T} L_{k}+r_{T} L_{k^{\prime}}+\delta_{T}\left(L_{k}+L_{k^{\prime}}\right) \varepsilon_{T} \\
l_{k k^{\prime} O}=\alpha_{T}+\beta_{T} L_{k^{\prime}}+r_{T} L_{k}+\delta_{T}\left(L_{k}+L_{k^{\prime}}\right) \varepsilon_{T}
\end{array}\right\}
$$

ここに， $V$ は速度， $L$ は船舶の長さ（垂線間長）であ り, 以下添字 $k, k^{\prime}$ は着目船と相手船を意味するものと する. $\alpha, \beta, \gamma, \delta$ は偏回帰係数であり, $\varepsilon$ は平均值 0 , 分散 1 の標準正規確率変数である. 式 (1) のランダム 項は, 操船者の経験, 天候等の本モデルで明示的に扱っ ていないランダム要素の影響を表わしている.

一方, 前節で述べた C.G.W.S.-距離 $l *$ は, 変針角 $\theta$
が一定であるとし, 衝突直径（船舶 $k, k^{\prime}$ の中心間距離 がこの 円直径より 小さい場合は衝突を意味する） $D_{k k^{\prime}}$ を

$$
D_{k k^{\prime}}=\left(B_{k}+B_{k^{\prime}}\right) / 2
$$

と定義すれば，幾何学的関係から

$$
\left.\begin{array}{l}
l_{k k^{\prime} H^{*}}=\frac{D_{k k^{\prime}}}{\sin \theta} \\
l_{k k^{\prime} T^{*}}=D_{k k^{\prime}} \cdot \frac{\left(V_{k}{ }^{2}+V_{k^{\prime}}{ }^{2}-2 V_{k} V_{k^{\prime}} \cos \theta\right)^{1 / 2}}{V_{k} \sin \theta} \\
\text { ただし } V_{k} \cos \theta_{k}>V_{k^{\prime}} \\
l_{k k^{\prime} O^{*}}=D_{k k^{\prime}} \cdot \frac{\left(V_{k}{ }^{2}+V_{k^{\prime}}{ }^{2}-2 V_{k} V_{k^{\prime}} \cos \theta\right)^{1 / 2}}{V_{k^{\prime}} \sin \theta} \\
\text { ただし } V_{k}<V_{k^{\prime}} \cos \theta
\end{array}\right\}
$$

と表わされる. 避航失敗確率は G.W.S.-距離 $l$ が C. G.W.S.-距離 $l^{*}$ より短い事象の確率であるので, 出会 いの条件下での 2 船の衝突確率は

$$
\begin{gathered}
P_{\mathrm{CH} \mid \text { ENC }}\left(k, k^{\prime}, V_{k}, V_{k^{\prime}} \mid \text { Encounter }\right) \\
=\text { Prob. }\left[l_{k k^{\prime} H} \leq l_{k k^{\prime} H^{*}} \mid \text { Encounter }\right] \\
P_{\mathrm{CT} \mid \text { ENC }}\left(k, k^{\prime}, V_{k}, V_{k^{\prime}} \mid \text { Encounter }\right) \\
=\operatorname{Prob} .\left[l_{k k^{\prime} T} \leq l_{k k^{\prime} T^{*}}, V_{k} \cos \theta\right. \\
\left.>V_{k^{\prime}} \mid \text { Encounter }\right] \\
P_{\mathrm{CO} \mid \mathrm{ENC}}\left(k, k^{\prime}, V_{k}, V_{k^{\prime}} \mid \text { Encounter }\right) \\
=\text { Prob. }\left[l_{k k^{\prime} O} \leq l_{k k^{\prime} O^{*}}, V_{k}\right. \\
\left.\quad<V_{k^{\prime}} \cos \theta \mid \text { Encounter }\right]
\end{gathered}
$$

で与えられる. 本来, 避航失敗確率は出会い時の 2 船間 の中心間隔により異なるはずのものであるが, 先に示し たように, 本モデルでは出会いが着目船の進路の延長線 上で生ずるとの仮定を設けているため，2船の相対位置 には依存せず, 船型と速度のみから規定される.

次に, 水路内での出会い確率を求める. 図一2 に示し たように, 水路に直角な方向に $x$ 軸をとり, 着目船と相 手船の $x$ 軸方向の位置を $x_{k}, x_{k^{\prime}}$ とし, 相対距離 $L_{k k^{\prime}}$ を

$$
L_{k k^{\prime}}=x_{k}-x_{k^{\prime}}
$$

と置くと, 出会いの条件は次式で与えられる.

$$
-D_{k k^{\prime}} \leq L_{k k^{\prime}} \leq D_{k k^{\prime}}
$$

水路を航行する船舶の航跡分布が正規分布とよい一致を みせ, その平均值と水路中央との距離 $\bar{x}$, 分散 $\sigma_{x}{ }^{2}$ が,

$$
\left.\begin{array}{l}
\bar{x}=a W \\
\sigma_{x}{ }^{2}=-7.170+0.105 W+2.168 Q_{L}
\end{array}\right\}
$$

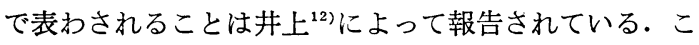
こにW $W$ 水路幅, $Q_{L}$ は $L$ 換算交通量であり, パラメ 一ター $a$ は中央線表示がある両側通航水路で 0.2 , 中央 線表示がない場合 0.1 の值をとる.この結果から, 対向 2 船および同航 2 船の相対距離 $L_{k k^{\prime}}$ の分布 $f_{H}\left(L_{k k^{\prime}}\right)$, $f_{T}\left(L_{k k^{\prime}}\right)$ は次式の正規分布で近似できることが導かれ 
る.

$$
\left.\begin{array}{l}
f_{H}\left(L_{k k^{\prime}}\right)=N\left(2 a W, \sigma_{x_{k}}{ }^{2}+\sigma_{x_{k^{\prime}}}{ }^{2}\right) \\
f_{T}\left(L_{k k^{\prime}}\right)=N\left(0, \sigma_{x_{k}}{ }^{2}+\sigma_{x_{k^{\prime}}}{ }^{2}\right)
\end{array}\right\}
$$

ここに, $\sigma_{x_{k}}{ }^{2}, \sigma_{x_{k^{\prime}}}{ }^{2}$ は着目船, 相手船の進行方向の航跡 分布の分散である. 式 (6) と式 (8) より, 船型 $k, k^{\prime}$ の 2 船に対する出会い確率は次式で求められる.

$$
\left.\begin{array}{l}
P_{\mathrm{ENC}}{ }^{H}\left(k, k^{\prime}\right)=\int_{-D_{k k^{\prime}}}^{D_{k k^{\prime}}} f_{H}\left(L_{k k^{\prime}}\right) d L_{k k^{\prime}} \\
P_{\mathrm{ENC}}{ }^{T}\left(k, k^{\prime}\right)=\int_{-D_{k k^{\prime}}}^{D_{k k^{\prime}}} f_{T}\left(L_{k k^{\prime}}\right) d L_{k k^{\prime}}
\end{array}\right\}
$$

式（4）および式（9）で与えられる避航失敗確率と出 会い確率の積として，3 種の避航形態についての船型別 基本衝突確率は次式で表わされることになる.

$$
\begin{aligned}
& P_{e \mathrm{CH}}\left(k, k^{\prime}, V_{k}, V_{k^{\prime}}\right) \\
&= P_{\mathrm{CH} \mid \mathrm{ENC}}\left(k, k^{\prime}, V_{k}, V_{k^{\prime}} \mid \text { Encounter }\right) \\
& \cdot P_{\mathrm{ENC}}{ }^{H}\left(k, k^{\prime}\right) \\
& P_{e \mathrm{CT}}(\left(k, k^{\prime}, V_{k}, V_{k^{\prime}}\right) \\
&= P_{\mathrm{CT} \mid \mathrm{ENC}}\left(k, k^{\prime}, V_{k}, V_{k^{\prime}} \mid \text { Encounter }\right) \\
& \cdot P_{\mathrm{ENC}}{ }^{T}\left(k, k^{\prime}\right) \\
& P_{e \mathrm{CO}}\left(k, k^{\prime}, V_{k}, V_{k^{\prime}}\right) \\
&= \\
& P_{\mathrm{CO} \mid \mathrm{ENC}}\left(k, k^{\prime}, V_{k}, V_{k^{\prime}} \mid \text { Encounter }\right) \\
& \quad \cdot P_{\mathrm{ENC}}{ }^{T}\left(k, k^{\prime}\right)
\end{aligned}
$$

\section{（4）出会い状態の隻数分布}

前に,「出会い」は 2 船が衝突直径内で遭遇する状態 を定義したのに対し，「出会い状態」とは以下の状態を いう. すなわち，着目船が水路内で行き合い，追い越 し，および被追い越しの状態になることをいい,「出会 い状態の隻数」とは, 着目船がこれらの状態で遭遇する 相手船舶の総隻数をいら（図一5 の船舶 $\mathrm{A}$ と B の間に ある総隻数)。ここでは，これら 3 つの状態での隻数分 布の求め方について述べる.

方向別交通量比を $\lambda$ とすると, 方向別の交通量は $Q_{1}$ $=\lambda Q, Q_{2}=(1-\lambda) Q$ で与えられる. ところで, 藤井 ${ }^{13)}$ によれば，通常の交通量における船型構成分布は，垂線 間長の常用対数 $\omega$ を用いて, $\phi(\omega)=N\left[\mu_{\omega}, \sigma_{\omega}{ }^{2}\right]$ なる正 規分布で近似できる．したがって，船型 $k$ の方向別期 待交通量 $Q_{1 k}, Q_{2 k}$ は次式で与えられる.

$$
\left.\begin{array}{l}
Q_{1 k}=\lambda Q \phi\left(\omega_{k}\right) \\
Q_{2 k}=(1-\lambda) Q \phi\left(\omega_{k}\right)
\end{array}\right\}
$$

いま，図一5（a）に示すように，水路端 $o_{1} o_{1}{ }^{\prime}$ に到 着した速度 $V_{k}$ の船 $\mathrm{A}$ が, $L_{C}+\Delta L_{H}$ 離れた位置を航 行する速度 $V_{k^{\prime}}$ の反航船と水路内で行き合う条件は,

$$
\Delta L_{H} \leq L_{C} \frac{V_{k^{\prime}}}{V_{k}}
$$

である.したがって, 船 A が水路を通過する間に行き

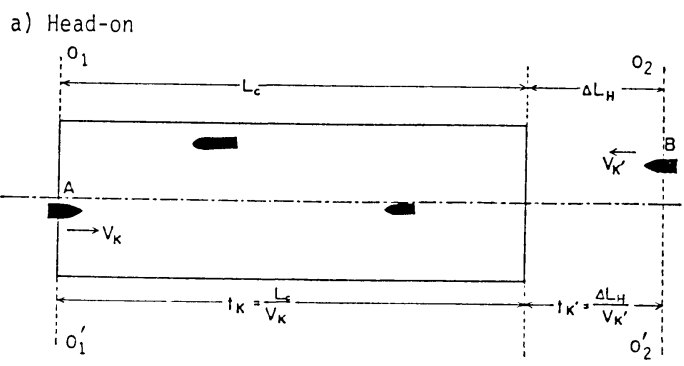

b) Overtaking

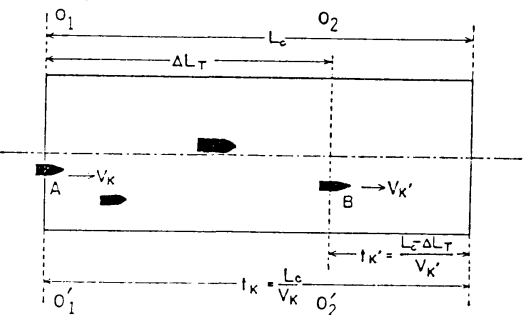

c) Overtaken

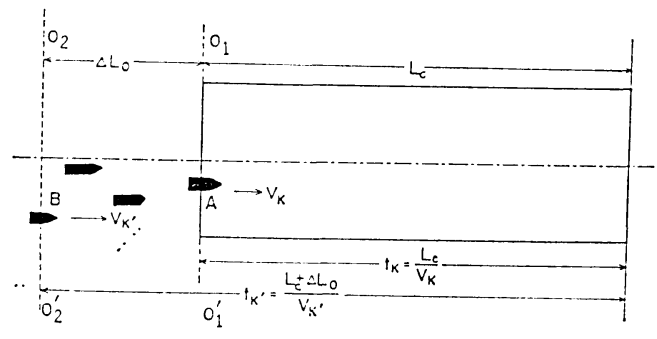

図一5 船舶 $\mathrm{A}, \mathrm{B}$ が出会うための最長距離

合う可能性のある船舶数は, 船 $\mathrm{A}$ が水路端に到着した 瞬間に水路端から $L_{C}+\Delta L_{H}$ の間に 存在する 船舶数で ある. 船 B が $L_{C}+\Delta L_{H}$ を進むに要する時間 $\delta t_{H}$ は，

$$
\delta t_{H}=\frac{L_{C}+\Delta L_{H}}{V_{k}{ }^{\prime}}=L_{C}\left(\frac{1}{V_{k^{\prime}}}+\frac{1}{V_{k}}\right)
$$

で与えられる．原 ${ }^{14}$ によると，定常交通流において任意 の時間内に見通し線 $\mathrm{O}_{2} \mathrm{O}_{2^{\prime}}$ に到着寸る隻数はポアソン分 布とみなせるので，ある時間間隔 $\delta t_{H}$ に $\mathrm{o}_{2} \mathrm{O}_{2}{ }^{\prime}$ を通過 する船型 $k^{\prime}$ の船の隻数を $n_{H k k^{\prime}}$ とすると，その確率 は次式で与えられる.

$$
P\left(n_{H k k^{\prime}}\right)=\frac{\left(Q_{2 k^{\prime}} \cdot \delta t_{H}\right)^{n_{H k k^{\prime}}}}{n_{H k k^{\prime}} !} \cdot e^{-Q_{2 k^{\prime}} \cdot \delta t_{H}}
$$

同様に，追い越し，被追い越しの場合についても図 -5 (b)，(c) を参照して, 着目船が出会い状態となる船 舶数が $n_{T k k^{\prime}}, n_{O k k^{\prime}}$ である確率 $P\left(n_{T k k^{\prime}}\right), P\left(n_{O k k^{\prime}}\right)$ は, 次式で与えられる.

$$
\begin{aligned}
& P\left(n_{T k k^{\prime}}\right)=\frac{\left(Q_{1 k^{\prime}} \cdot \delta t_{T}\right)^{n_{T k k^{\prime}}}}{n_{T k k^{\prime}} !} \cdot e^{-Q_{1 k^{\prime}} \delta t_{T}} \\
& \delta t_{T}=L_{C} \cdot\left(\frac{1}{V_{k^{\prime}}}-\frac{1}{V_{k}}\right) \\
& P\left(n_{O k k^{\prime}}\right)=\frac{\left(Q_{1 k^{\prime}} \cdot \delta t_{0}\right)^{n} O k k^{\prime}}{n_{O k k^{\prime}} !} \cdot e^{-Q_{1 k^{\prime}} \delta \delta t}
\end{aligned}
$$




$$
\delta t_{o}=L_{C} \cdot\left(\frac{1}{V_{k}}-\frac{1}{V_{k^{\prime}}}\right)
$$

\section{（5）水路における衝突危険度}

船舶が 水路内で衝突する確率は，衝突することなく 水路を通過する事象の余事象の確率として計算される. 行き合い状態のすべての船舶に対し衝突しない確率 $P_{S H k k^{\prime}}$ は,

$$
P_{S H k k^{\prime}}=\sum_{n_{H k k^{\prime}}=0}^{\infty}\left[1-P_{e C H}\left(k, k^{\prime}\right)\right]^{n_{H k k^{\prime}}} \cdot P\left(n_{H k k^{\prime}}\right)
$$

であるが, $P_{e C H}\left(k, k^{\prime}\right) \ll 1$ (後に示す試算では $10^{-3}$ の オーダー) であるので，上式は次式のように簡単にする ことができる.

$$
\begin{aligned}
P_{S H k k^{\prime}}= & \sum_{n_{H k k^{\prime}}=0}^{\infty}\left[1-n_{H k k^{\prime}} \cdot P_{e \mathrm{CH}}\left(k, k^{\prime}\right)\right] \\
& \cdot P\left(n_{H \boldsymbol{k} k^{\prime}}\right)=1-\overline{n_{H k k^{\prime}}} \cdot P_{e \mathrm{CH}}\left(k, k^{\prime}\right)
\end{aligned}
$$

上式において, $\overline{n_{H k k^{\prime}}}$ は船型 $k$ の船が出会い状態にな る船型 $k^{\prime}$ の反航船の平均隻数である. 同様に, 追い越 乙状態および被追い越し状態での非衝突確率 $P_{S T k k^{\prime}}$, $P_{S O k k^{\prime}}$ もそれぞれ次式のごとくなる.

$$
\begin{aligned}
& P_{S T k k^{\prime}}=1-\overline{n_{T k k^{\prime}}} \cdot P_{e \mathrm{CT}}\left(k, k^{\prime}\right) \\
& P_{S O k k^{\prime}}=1-\overline{n_{O k k^{\prime}}} \cdot P_{e \mathrm{CO}}\left(k, k^{\prime}\right)
\end{aligned}
$$

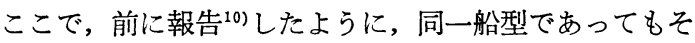
の航行速度は正規確率変数として考えられるので，その 確率密度関数を $f .(V$.$) とすると, 期待される非衝突確$ 率はそれぞれ式 (23)〜 (25) で与えられる.

$$
\begin{aligned}
& \overline{P_{S H k k^{\prime}}}=\int_{0}^{\infty} \int_{0}^{\infty} P_{S H k k^{\prime}} f_{k}\left(V_{k}\right) f_{k^{\prime}}\left(V_{k^{\prime}}\right) d V_{k} d V_{k^{\prime}} \\
& \overline{P_{S T k k^{\prime}}}=\int_{0}^{\infty} \int_{0}^{V_{k} \cos \theta} P_{S T k k^{\prime}} f_{k}\left(V_{k}\right) f_{k^{\prime}}\left(V_{k^{\prime}}\right) d V_{k} d V_{k^{\prime}} \\
& \overline{P_{S O k k^{\prime}}}=\int_{0}^{\infty} \int_{V_{k} / \cos \theta}^{\infty} P_{S O k^{\prime}} f_{k}\left(V_{k}\right) f_{k^{\prime}}\left(V_{k^{\prime}}\right) d V_{k} d V_{k^{\prime}}
\end{aligned}
$$

ある船型 $k$ の船舶が衝突することなく水路を通過す る確率は，すべての避航形態，すべての船型に対して衝 突しない確率であるから, 船型 $k$ の船舶の期待衝突確 率 $P_{C k}$ は,

$$
P_{C k}=1-\int_{k^{\prime}}\left\{\overline{P_{S H k k^{\prime}}} \cdot \overline{P_{S T k k^{\prime}}} \cdot \overline{P_{S O k k^{\prime}}}\right\} \cdot \phi\left(\omega_{k^{\prime}}\right) d \omega_{k^{\prime}}
$$

で与えられる.上式は, 船型 $k$ なる着目船が水路 $L_{C}$ を ある方向（交通量 $\lambda Q$ の方向）に通過する間に期待さ れる平均的衝突確率である.

以上より, ある交通特性を考えたとき, 所与の水路で のある方向の 1 トリップ当たりの平均的な衝突確率 $P_{C}$ は, 次式で与えられる.

$$
P_{C}=\int_{k} P_{C k} \phi\left(\omega_{k}\right) d \omega_{k}
$$

上式は，一定の交通特性のもとで，ある水路で期待され る衝突危険度を示すもので, その水路の航行安全性を示 す一つの指標と考えられる.

\section{3. モデルの妥当性の検討}

前章で導いた水路に扔ける船舶衝突確率推定モデルの 妥当性を検討するため, わが国のいくつかの主要狭水道 に対して試算を行い，実績值と比較する.

\section{(1) 入カデータ}

試算例とした狭水道は交通量・事故件数が大であり， 船型構成に占める大型船の比率が小さくない浦賀水道, 明石海峡, 備讃瀬戸東部, 来島海峡の 4 か所である.

モデルへの入力となる水路特性, 交通特性吕を 表一2 に示す.

表一2 モデル比較のための入カデータ （水路・交通特性）

\begin{tabular}{c|c|c|c|c|c|c|c}
\hline Channel & $L_{C}$ & $W$ & $Q$ & $\mu_{\log L}$ & $\sigma_{\log L}$ & $\lambda$ & $a$ \\
\hline AKASHI & 18.5 & 4.0 & 68.8 & 1.36 & 0.26 & 0.50 & 0.20 \\
URAGA & 28.0 & 2.0 & 33.5 & 1.53 & 0.26 & 0.50 & 0.20 \\
BISAN EAST & 35.7 & 2.0 & 44.5 & 1.43 & 0.20 & 0.50 & 0.20 \\
KURUSHIMA & 27.8 & 2.0 & 35.9 & 1.30 & 0.30 & 0.50 & 0.20 \\
\hline
\end{tabular}

表に示した交通特性のうち，船型構成分布を規定する パラメーター $\mu_{\log L}$ と $\sigma_{\log L}$ は, 日本海難防止協会 ${ }^{15)}$ による各狭水道における船型別交通量の観測結果より求 めた. 方向別交通量比 $\lambda$ は時刻により変化するもので あるが，1 日単位でみた場合両方向ともほぼ交通量は等 しく,ここでは一律に 0.5 とした.

船舶特性については, 船型別平均航行速度 $\mu_{V_{k}}$, 船幅 $B_{k}$ を垂線間長 $L$ と関連づけて取り扱い, 藤井 ${ }^{16)}$ によ る次式を用いた。

$$
\begin{aligned}
& \log \mu_{V_{k}}=0.29 \log L_{k}+0.79 \\
& \log B_{k}=0.88 \log L_{k}-0.47
\end{aligned}
$$

また, 航行速度分布の 標準偏差 $\sigma_{V_{k}}$ は藤井 $^{17)}$ によりす べての船型に対して $2.78 \mathrm{~km} / \mathrm{h}(1.5 \mathrm{knot})$ とし, 避航 の際の変針角 $\theta$ は通常の避航動態を考えて $30^{\circ}$ とした. 式（1）で示した避航開始距離分布のパラメーター $\alpha_{H}$, $\beta_{H}, \gamma_{H}, \delta_{H}$,およ び $\alpha_{T}, \beta_{T}, \gamma_{T}, \delta_{T}$ は運輸省第三港湾 建設局の実態調查 資料 ${ }^{11)}$ 上り 表一3 の值を得た. 図一
表一3 避航開始距離分布の 偏回誉係数

\begin{tabular}{c|r|c|c|c}
\hline & \multicolumn{1}{|c|}{$\alpha$} & $\beta$ & $\gamma$ & $\delta$ \\
\hline$H$ & -931.4 & 4.59 & 4.59 & 220.0 \\
$T, O$ & 87.1 & 6.40 & 1.60 & 2.45 \\
\hline
\end{tabular}

$H$ : Head-on, $T:$ Overtaking,

$O$ : Overtaken 


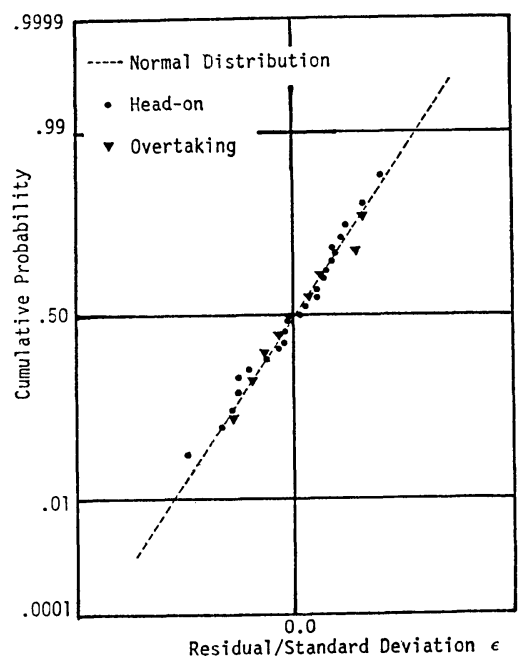

图一6 避航開始距離のランダム変数の分布

6 は実績值 $\bar{l}_{k k^{\prime} H}, \bar{l}_{k k^{\prime} T}$ と推定值 $l_{k k^{\prime} H}, l_{k k^{\prime} T}$ の残差 をそれぞれ $\delta_{H}, \delta_{T}\left(L_{k}-L_{k^{\prime}}\right)$ で基準化して正規確率紙 上にプロットしたものである. データ数は少ないが， $\varepsilon$ を標準正規分布と仮定しても大きな誤ちはないと考えら れる.

\section{（2）計算結果と実績值との比較}

以上の入力データを用いて求めた船舶衝突確率の推定 值と実績值の対応を示したものが 図一7である. 実績值 は日本海難防止協会 ${ }^{15)}$ による值を用いた。 ここで，小型 船，中型船，大型船がそれぞれ 500 G.T., 500 3000 G.T., 3000 G.T.〜，に対応し，計算にあたっては，各 船型ランクの平均垂線間長 $32.9 \mathrm{~m}, 66.5 \mathrm{~m}, 122.1 \mathrm{~m}$ を 有する船舶を代表船型として求めた.ここで示した衝突 確率 $P_{C}$ は 1 トリップ当たりの衝突確率であり, 単位 は (回/トリップ) である. 総体的に やや過大な 推定と なっているが, $45^{\circ}$ 線にほぼ沿っており, 水路特性, 交 通特性がそれぞれ異なる各狭水道における船舶衝突確率 をその特性と関連ゔけて説明し得たといえよう．したが

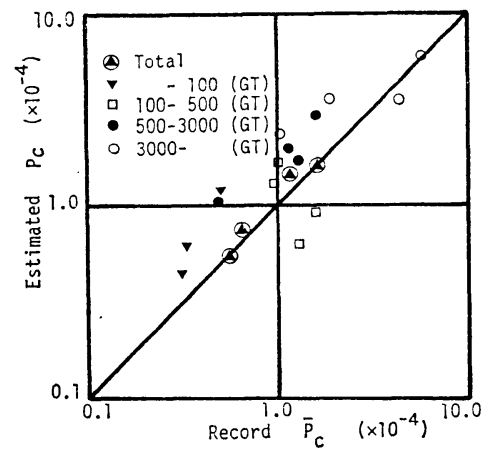

図一7推定颠と実績值の比較（本モデル）
って, 本モデルを用いて水路改良効果, すなわち, 水路 改良による相対的な航行安全性の変化を予測することが できる.

次に, 本モデルの結果と, 同一データで計算した従来 のモデルの結果を比較する．なお，各モデルの内容につ いては簡単な説明にとどめ, 詳細は参考文献を参照され たい.

原のモデル ${ }^{5), 6)}$ は，一連の避航を待ち行列系に抢ける サービスと考え, サービス時間に相当する平均避航所要 時間 $(1 / \mu)$ と避航すべき相手船の到着時間間隔から計

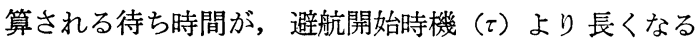
確率を衝突確率とするものである．先に用いた入力デー タ以外に用いた数值は原が示した值一使用舵角 $15^{\circ}$, 操 舵速度 $2.33(\mathrm{deg} / \mathrm{s})$, 操縦性指数 $T^{\prime}=2.5, K^{\prime}=1.8$, 上 述の $\tau=3.5(\mathrm{~min}), 1 / \mu=0.8(\mathrm{~min})$ 一に従った. また， このモデルは水路の湾曲の影響も考虑しており, 水路の 平均湾曲角度 $\psi_{m}$ だけ変針するために 要する 航走距離 $e$ は, $\psi_{m}$ 変針する際の新針路距離の 2 倍で代用した. その他の水路特性值は 原の示すデー夕を用いた. 図一8 が原のモデルによる推定值と実績值を対応させたもので ある.ただし，小型船の推定值の一部は $0.1 \times 10^{-4}$ 以下 ときわめて小さな值であるため図示していない．

藤井のモデル ${ }^{99}$ は, 船舶の大きさと航行速度, 出会い 角度, 船舶密度等から, 船舶が避航することなく直進し た場合に衝突する船舶数を幾何学的関係から求め, 実績 值に合うよう統計的な衝突直径なる概念を導入して補正 するものである．藤井のモデルによる推定值と実績值の 対応を同じく図一8 に示すが，統計的な衝突直径は水 路を航行する全船舶の平均船舶長に対して求められてい るため,ここでは全船型に対する值のみをプロットして ある．計算に用いた統計的な衝突直径の值は，反航の場 合 $3.0 \times 10^{-4} \mathrm{~L}$, 同航の場合 $1.0 \times 10^{-4} \mathrm{~L}$ とした ${ }^{18)}$.

以上の結果を比較すると, 数值的には図からも明らか なように，原のモデルは小型船について特に推定值が小

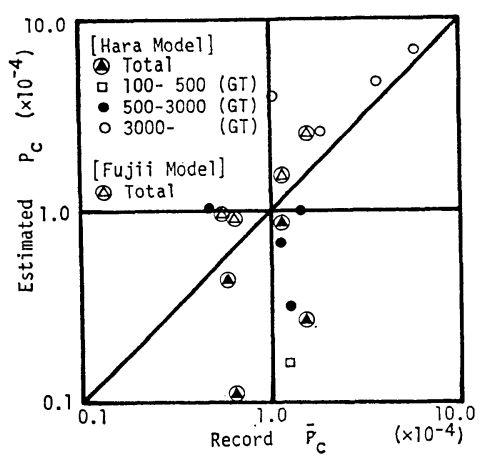

図一8 推定值と実縝値の比較（原モデル， 藤井モデル) 
さくなっている，藤井のモデルと本モデルは，どちらも やや過大な推定となってはいるものの, 傾向的には現象 をほぼ再現しているとみることができる.モデルの性格 の面では, 原のモデルおよび本モデルは避航動態とその 失敗確率を考慮したものであり,さらに, 原のモデルは 水路の湾曲や多重遭遇をも考虑に含めた形となっている が, 藤井のモデルは避航動態を考慮に入れず, 補正率的 な性格をもった統計的衝突直径なる概念を対応づけのた め与えているにすぎない. したがって, 藤井のモデルは 船舶交通特性や水路特性が変化した場合の危険度を予測 するモデルとしては使用できない.

このように, 水路の改良計画や航行規制, さらには衝 突防止機器の改良といった多方面からの船舶衝突事故率 低減施策の効果を定量的に把握するための道具として, 現象説明力ならびにモデルの性格の点で, 従来のモデル と比べ本研究で提案するモデルの方がより適切であると 考えられる.

\section{4. 本モデルに残る課題}

本推定モデルの各プロセスに存在する問題点を列挙 し，以下これらに対する議論を行う。

その 1 は, 本モデルが 1 船対 1 船の避航動態をもとに 構筑されたものであるため, 避航の対象となる船舶の近 傍を航行する他船の影響および避航動態に与える水路側 端の影響が考慮されていないことである.実際の避航に あたっては，周辺を航行する全船舶の位置と相対運動を 認識した後, たとえば船舶密度の低い側へ避航したり, 場合によっては減速して追い越しを中止することもあり 得る.このような挙動が衝突確率に及ぼす影響を考慮に 入れ, 水路内での船群の発生や多重遭遇等, 混雑流内で しばしばみられる現象を取り扱うためには，2 体問題の みならず多体問題を記述し得るモデルへと抎張すること が必要となる.

その 2 は，用いた関係式についてである. 本モデルで 用いた航行船舶の動態に関する諸関係式は, 種々の状況 のもとでの，かつ十分豊富なサンプル数を有するデータ をもとにして導かれたとはいいがたいものがある．船舶 挙動に関しては, 船舶諸特性のばらつきが大きくかつ 2 次元的に運動しているため, 検討すべき要因の数が道路 交通に比してはるかに多いこと，反射的といっていいほ ど迅速な運転動作が要求される自動車交通に比べ航行挙 動に対する操船者の Human Factor の影響は支配的で あり，それが操船環境に左右されやすいこと等を考え併 せると, 必要かつ十分な要因によって説明される関係式 の導出は困難であるとは思われるが, さらなる観測デー タの蓄積と精度の向上が望まれる.
その 3 は，モデル化の際に混入する誤差である. 本モ デルでは, 転舵時の航跡を直線で近似したこと, 他船と の接近時の吸引力の効果を無視したこと等, 記述を簡略 にするための船体運動の単純化に伴う誤差が混入してい る.しかしながら，この誤差はモデルの使用目的一たと えば水路相互の大略的な衝突確率の比較を行ら場合や, 個々の設計代替案の安全面の評価等一に照らして十分な 精度であると考えられる.

その 4 は, 分布形のあてはめ関する問題である.す なわち, 実際の現象は有限領域でしか生起しないにもか かわらず，無限領域で定義される分布形を当てはめてい ることである。

以上に述べたようなモデルに含まれている諸問題は今 後の検討課題として残されている.

なお，最後に，モデルを検証する際の一般的な問題と して, 実績值の精度の問題が議論されねばならない. 衝 突確率の実績值は, 各水路における衝突隻数と通航総隻 数の比であるが, 前者の記録として「海難統計」,「海難 速報」「要救助海難統計」のどれをとるかにより衝突隻 数熼なるものとなる. また, 交通量調査は, 主要狭水 道についてはほぼ毎年定期的に実施されているが，おお む称 3 日間調查であり, 年平均交通量がどの程度正確に 推定されているかも問題となる.さらに, 衝突確率が年 度によってばらつきがあるにもかかわらず，現在のとこ ろ長期にわたる記録が完備していると法いえない。これ らの点を考え合わせると，3. で示した衝突確率の実績 值も幾分幅をもたせて考えるべきである.したがって, モデルの妥当性もこのことを念頭に置いて論じられるべ きである.

\section{5. 結言}

航路計画において水路の評価を行う際, 交通事故的海 難に対する航行安全性は水路の混雑度を表わす一つの指 標とすることができる. ある特性を有する水路で, 交通 量が増大するほど安全性は低下し, 逆に安全性を一定の 水準以上に保つためには交通量に上限を設ける必要があ る. 寸なわち, 水路の交通容量は安全性の面からも規定 される.

これまでに提案されてきた航路計画の評価指標として は, 待ち時間 ${ }^{19}$ や避航確率 ${ }^{20)}$, 安全保数 ${ }^{21)}$ が用いられて いる.これらの指標に加え, 本モデルで提案したような 安全性を示す指標も同時に水路の評価に用いることがで きる. 今後, これらの指標間の関倸を明らかにし, 総合 的な水路計画に用いられるようにする必要がある.

本研究で得られた結果を以下に列挙する.

（1）避航動態を考慮した運動学的な船舶衝突確率推 
定モデルを構築し, 水路特性・交通特性と衝突確率とを 関連づけた.

（2）過去の実績值と提案したモデルによる推定值を 比較し,よい一致をみた。

（3）従来提案されているモデルとの比較検討を行 い，水路の安全性向上のための施策の探索と代替案評価 を行らための道具として, 本モデルがより適切であるこ とを示した.

（4）本モデルあるいは船舶交通流の挙動解析モデル 一般が有するいくつかの問題点に関して議論を行い，今 後のモデル改良の方向を明らかにした.

なお, 本モデルは横断船舶が存在しない場合に限定し て構築されたものである. 現実の水路にはその数の多少 は別として横断船舶が航行しており, 本モデルの適用に は限界があるため, 引き続き航路交差部を扱い得るモデ ルへと拡張を図る必要があることを述べておく．

最後に, 本研究は昭和 56 年度文部省科学研究費補助 金を受けて行われたものであることを付記する。

\section{参 考 文 献}

1）福島 弘：海難防止論, 成山堂, p. 35, 1972.

2) 同上, p. 59 .

3）杉崎昭生ほか：航路設計 のための 海上交通容量 $\mathrm{I} \sim \mathrm{VI}$, 日本航海学会論文集, No. 50, pp. 39〜45, 1973 ほか.

4）木俣 昇・石崎肇士：シミュレーションによる 航路計画 の研究, 土木学会論文報告集, No. 194, pp. 113～126, 1971.

5）原 潔：船の衝突確率を任意の水域で推定する方法につ いて, 日本航海学会誌, No. 46, pp. 191 200, 1971.

6）原 潔: 避航システムモデルによる衝突確率の考察, 日
本航海学会論文集, No. 50, pp. 29 38, 1973.

7) Curtis, R.G. : An Analysis of the Dangers of Ships Overtaking, Mathematical Aspects of Marine Traffic, Academic Press, pp. 175 191, 1979.

8）藤井弥平ほか：海上交通工学, 海文堂, pp. 80 83, 1981 .

9) Lewisson, G.R.G. : The Modelling of Marine Traffic Flow and Potential Encounters, Mathematical Aspect of Marine Traffic, Academic Press, pp. 129 159. 1979.

10) Kuroda, K., H. Kita and S. Kono : Mathematical Model of Ship Collision Probability, Memoirs of the Fac. of Eng., Kyoto University, Vol. XLIV, Part 1, pp. 135 $\sim 157,1982$.

11）運輸省第三港湾建設局 : シーバース計画調查報告書, pp. $18 \sim 22,1974$.

12）井上欣三：值線航路における航跡分布のモデル化と航路 分離に関する一考察, 日本航海学会論文集, No. 58 , pp. 103 115, 1977.

13）藤井弥平: 序説海上交通工学, 海文堂, p. 89, 1971.

14）原 潔: 船舶交通の統計的特性一I, 日本航海学会誌, No. 35, pp. $77 \sim 83,1966$.

15）日本海難防止協会 : 海上の交通安全に関する 調査研究完 了報告書, p. $37,1970$.

16）前掲 13), p. 25, p. 32 .

17）藤井弥平 : 水路の基本航行容量の一試算, 日本航海学会 誌, No. 36, pp. 7 14, 1967.

18）藤井弥平：船の衝突直径と衝突発生率, 日本航海学会誌, No. 42, pp. 1 8, 1969.

19）奥山育英ほか：輸送ネットワークの評価 シミュレーショ ンの抬張, 土木学会第 32 回年次学術講演会講演概要集第 4 部, pp. 167 168, 1977.

20）運輸省第三港湾建設局：大阪湾船舶避航確率調查報告書, 1981.

21) Goodwin, E. and R.B. Richardson : Strategies for Marine Traffic, J. of Navigation, Vol. 33, No. 1, pp. 40 48, 1980.

(1982.10.25 - 受付) 